\title{
FORMATION OF A CORPORATE SOCIAL RESPONSIBILITY STRATEGY OF COMPANIES IN EU COUNTRIES
}

\author{
Andrii Kovban' ${ }^{1}$ Inna Kohut ${ }^{2}$
}

\begin{abstract}
Business cannot act in isolation from society since it itself is a part of society. The fact that corporate social responsibility (hereinafter - CSR) has become a global business concept that defines key ideas and a modern format for entrepreneurship is no longer questionable. Every year, more and more companies are joining the initiative of non-financial reporting, which acts as a "business card of a social image." The presence of social and ethical business standards greatly contributes to the formation of a positive business image and increases corporate competitiveness. At the same time, the growth of social, environmental, and economic problems of a global scale raises public expectations and, therefore, requirements for socially responsible activities of companies, inducing them to continuously improve the quality of CSR practices, finding innovative approaches to solving socially important problems, which is reflected in the global development trends of socially responsible business. The formation of models of state regulation of corporate social responsibility (CSR) in developed countries took place over several decades and, at the present stage, they are characterized by a high degree of development. The author aims to study the genesis of development of models of state regulation of corporate social responsibility, analyse principles of the formation of social responsibility strategy, and propose areas for improving CSR for companies operating in the European business space at the modern development stage in view of implementing the concept of sustainable development. After analysing the national models of CSR state regulation, we note that in the research of scientists, there from three (American, European, Asian) to seven models: American (US), European (Continental), British, Scandinavian, Asian (Japanese), African, model of BRICS countries or more. But, of course, the US model of CSR, formed in the specific conditions of the free market, is the largest. Key conclusions of the involvement of European companies in the implementation of the CSR strategy are as follows: involvement depends on the size of the company (CSR policy is applied by $48 \%$ of small and $65 \%$ of medium-sized companies); the implementation of the CSR policy does not depend on the company's field, but there was a geographical discrepancy (for example, $33 \%$ of the SME in France and $83 \%$ in Finland); among all companies, 50\% use the CSR strategy; only $8 \%$ of the EU company receive privileges or subsidies from the state for implementing the CSR policy; more than $75 \%$ of SME representatives among respondents can determine the benefits of corporate social responsibility. In the majority of the EU countries, state programs of support and stimulation of the abovementioned processes, in which the state defines socially responsible behaviour for business, engages private and public sector companies in the joint fulfilment of socially important tasks, stimulates business to socially responsible activity, are developed and operate. On the basis of determining the factors influencing the formation of social responsibility strategy and matrix of the appropriateness of SRB introduction, areas for improving strategic management based on social responsibility standards were formed.
\end{abstract}

CSR - corporate social responsibility; SRB - social responsibility of business; SR - social responsibility.

Key words: corporate social responsibility (CSR), national models of CSR, social business strategy, sustainable development, matrix of appropriateness, CSR strategy directions.

JEL Classification: M14, J24, D30, H70

\footnotetext{
Corresponding author:

${ }^{1}$ National University "Odessa Maritime Academy", Ukraine.

E-mail: a.kovban@gmail.com

ORCID: https://orcid.org/0000-0002-0272-1798

ResearcherID: H-4297-2016

${ }^{2}$ Odesa State Agrarian University, Ukraine.

E-mail: innakogut10@gmail.com
} 


\section{Introduction}

Business cannot act in isolation from society since it itself is a part of society. The fact that corporate social responsibility (hereinafter - CSR) has become a global business concept that defines keyideas and a modern format for entrepreneurship is no longer questionable. Every year, more and more companies are joining the initiative of nonfinancial reporting, which acts as a "business card of a social image". The presence of social and ethical standards of a business greatly contributes to the formation of a positive business image and increases corporate competitiveness.

At the same time, the growth of social, environmental, and economic problems of a global scale raises public expectations and, therefore, requirements for socially responsible activities of companies, inducing them to continuously improve the quality of CSR practices, finding innovative approaches to solving socially important problems, which is reflected in the global development trends of socially responsible business.

The formation of models of state regulation of corporate social responsibility (CSR) in developed countries took place over several decades and, at the present stage, they are characterized by a high degree of development. In world literature, the most famous publications on CSR are works by M. Albert, P. Drucker, A. Carroll, P. Kotler, M. Porter, W. Hoyer, F. Hayek, M. Friedman, and others.

It should be noted that there is no consensus on the reasons for the emergence of the SRB phenomenon in professional research. Among the most commonly mentioned preconditions are the general tendency towards labour humanization, the development of the trade union and consumer movements, and the personal initiative of such prominent entrepreneurs as Andrew Carnegie, John D. Rockefeller, Nathan Rothschild, and others. However, it is undoubtedly that the direct driving force of SRB development was the concentration of capital, which provided the business with sufficient material, financial, intellectual resources, as well as socio-political weight to influence the socio-economic processes in the appropriate country (Voronchak, 2018).

The author aims to study the genesis of development of models of state regulation of corporate social responsibility, analyse principles of the formation of social responsibility strategy, and propose areas for improving CSR for companies operating in the European business space at the modern development stage in view of implementing the concept of sustainable development.

\section{The methodology of research}

\section{Formation and development of CSR models in the world}

The term "corporate social responsibility" is borrowed from English-language scientific literature. In this context, a corporation is considered as any legal entity whose main purpose is profit-making (Zhmay, 2015). Today, there are many variants of interpretation of the definition of CSR, but they all agree that corporate social responsibility is the responsibility of business to all components of society (they can include partners, consumers, employees of the company, etc.).

P. Kotler's definition is considered a classic: "corporate social responsibility is a commitment to improve community well-being through discretionary business practices and contributions of corporate resources" (Kotler, Li, 2005).

Since the early 90 s of the XX century, there has been a steady increase in the number of companies that systematically publish social reports, thus demonstrating their commitment to CSR policies. If in 1993 non-financial reports were released only by about $12 \%$ of business representatives, then in 2013 this indicator increased almost 6 times and accounted for $71 \%$ of the largest companies in 41 countries of the world (Zhmay, 2015).

After analysing the national models of CSR state regulation, we note that in the research of scientists, there from three (American, European, Asian) to seven models: American (US), European (Continental), British, Scandinavian, Asian (Japanese), African, model of BRICS countries or more (Olijnik, 2015). But, of course, the US model of SRB, formed in the specific conditions of the free market, is the largest. The main features of the American model are: focus on specific issues, focus on philanthropy and volunteering, partnerships with nonprofit organizations and leaders of local communities. An important element of the American model of SRB - the developed infrastructure of business participation in social support of society: a significant number of corporate funds focused on solving social problems at the expense of business (education, medicine, environmental projects). The role of the state is to encourage social initiatives of companies through a system of tax incentives (Voronchak, 2018).

The European SRB model can be characterized as a mechanism for companies to achieve their own business goals under rough conditions of state/ public regulation and control. Typical objects of social investment: human capital, social insurance, human rights, development of science and education, environmental activity (Voronchak, 2018). A key feature of SRB practice is its established institutional support, both at the level of individual countries and the EU as a whole. State regulation is carried out by permanent government structures on the basis of special legislation. Social reporting, certification according to international CSR standards, contractual relations with trade unions and state/municipal institutions are widespread.

The British SRB model is mostly characterized as a symbiosis of American and continental (European) approaches, which combines business initiative in the selection of SRB fields with the active participation of 
the state and civil society institutions in corporate social investment. Its features are: attention of the financial sector to SRB (development of socially responsible investment funds), the significant role of mass media, dissemination of SRB training courses in the system of business education, developed system of cooperation with stakeholders (Olijnik, 2015). SRB in Japan is based on the specific labour relations and traditions of the country where the company is perceived as a "production family", employment is practiced under "lifelong employment", and the business purpose is to ensure the harmony of the interests of owners, workers, and society. The main directions of SRB in the Asian model are: ecology (climate change, ecosystem conservation) and labour relations (housing payment for employees, their training, childbirth assistance, corporate pensions), which ensures the stability of human resources, creating an atmosphere of participation and shared responsibility (Bodnaruk, 2016). The active role of the state in strategic planning and standardization of SRB is supplemented by activities of national and sectoral business associations that form their own social and environmental standards.

Therefore, ant national model of SRB can be analysed in the two-dimensional coordinate system (scale of response to social needs; the degree of state regulation of business participation in social development) (Voronchak, 2018).

This approach, appropriate for a general comparison of SRB models, has a limited value in terms of their characteristics. For such purposes, it is more appropriate to compare national SRB models by a definite list of their main features (Table 1). It is obvious that in each case, the set of characteristics is not random but was formed in the process of developing the model as a consequence of a specific combination of external and internal factors.

In Central Europe, corporate social responsibility is being promoted by public authorities. So, in Italy, the Ministry of Labour and Social Policies is monitoring the process of CSR development and social reporting. In Spain, the left-wing parties actively contributed to the adoption of the CSR Law by the Parliament in 2003. Spain has a State Expert Technical Commission for CSR, whose mission is to "help businesses combine economic activity with activities for the benefit of society" (Socialna vidpovidalnist biznesu, 2017). Lithuania has developed a CSR strategy for 2006-2008, the implementation of which allowed improving the country's position during 2006-2008. In Poland, the Ministry of Labour created a CSR Working Group, which included representatives of many departments whose activities contributed to a more or less stable position of this country during 2004-2010 in the world ranking of social philanthropy (Voronchak, 2018).

A certain combination of the models described is the situation with SRB in Great Britain. Along with the high voluntary activity of businesses in the field of social responsibility and sustainable development, there are also serious government initiatives (for example, the creation of public-private partnerships, the introduction of tax incentives for responsible companies, etc.).

Governments of different countries sanction social responsibility, for example, when applying the requirement for mandatory reporting to companies when they are obliged to apply environmental management systems, etc. As soon as these obligations, norms, and rules underlying them become formally fixed, they become "regulated SRB".

Table 1

Comparative characteristics of the main national SRB models

\begin{tabular}{|c|c|c|c|c|}
\hline \multirow{2}{*}{ Key feature } & \multicolumn{4}{|c|}{ Country of origin of the SRB model } \\
\hline & USA & European countries & Great Britain & Japan \\
\hline $\begin{array}{l}\text { The initiator of the } \\
\text { introduction of SRB } \\
\text { standards }\end{array}$ & Business & $\begin{array}{l}\text { State, institutes of civil } \\
\text { society }\end{array}$ & $\begin{array}{l}\text { Business, institutes of civil } \\
\text { society }\end{array}$ & Big business \\
\hline $\begin{array}{l}\text { The role of the state } \\
\text { in SRB }\end{array}$ & $\begin{array}{l}\text { Minimum regulation, tax } \\
\text { privileges }\end{array}$ & $\begin{array}{l}\text { Regulation by means of } \\
\text { laws and standards }\end{array}$ & $\begin{array}{l}\text { Development of social and } \\
\text { environmental standards }\end{array}$ & $\begin{array}{l}\text { The state is a customer, } \\
\text { a controller, and an SRB } \\
\text { beneficiary }\end{array}$ \\
\hline $\begin{array}{l}\text { The perception of } \\
\text { business in society }\end{array}$ & $\begin{array}{l}\text { Lack of traditions of } \\
\text { confrontation and conflicts } \\
\text { in the labour sphere, } \\
\text { the insignificance and } \\
\text { conformism of trade unions }\end{array}$ & $\begin{array}{l}\text { Search for a social } \\
\text { compromise between } \\
\text { labour and hired capital }\end{array}$ & $\begin{array}{l}\text { Awareness of the economic, } \\
\text { social, and environmental } \\
\text { role of business, trade } \\
\text { union traditions }\end{array}$ & $\begin{array}{l}\text { Perception of the } \\
\text { company as a "big family", } \\
\text { recognition of the social } \\
\text { role of business }\end{array}$ \\
\hline Key stakeholders & $\begin{array}{l}\text { Shareholders, consumers, } \\
\text { mass media, local } \\
\text { communities, poor people }\end{array}$ & $\begin{array}{l}\text { Consumers, employees, } \\
\text { state, public organizations }\end{array}$ & $\begin{array}{l}\text { Consumers, business } \\
\text { partners, trade unions, mass } \\
\text { media }\end{array}$ & $\begin{array}{l}\text { Employees, consumers, } \\
\text { local communities }\end{array}$ \\
\hline $\begin{array}{l}\text { Social values and } \\
\text { cultural features }\end{array}$ & $\begin{array}{l}\text { Individualism, persistent } \\
\text { work, leadership, } \\
\text { competition, prosperity, } \\
\text { citizen activism }\end{array}$ & $\begin{array}{l}\text { Pragmatism, the priority } \\
\text { of personal and family } \\
\text { interests, solidarity, well- } \\
\text { being }\end{array}$ & $\begin{array}{l}\text { Economic rationality, } \\
\text { individualism, } \\
\text { traditionalism }\end{array}$ & $\begin{array}{l}\text { Collectivism, paternalism, } \\
\text { modesty, respect for } \\
\text { traditions, mutual help }\end{array}$ \\
\hline
\end{tabular}

Source: Bodnaruk, 2016; Voronchak, 2018; Zhmay, 2015 
Such a trend has become dominant in many European countries in recent years. Relations between companies both in the European Union and in other countries are increasingly based on the principles of CSR. Adherence to these principles becomes an important prerequisite for attracting foreign investment and obtaining government orders. Among the European institutions, the European Commission's committees play a key role in disseminating the idea of CSR.

\section{Results and discussion}

\subsection{Key theoretical research results}

In order to compare the level of CSR development in different countries, a matrix that was developed by KPMG can be applied (Figure 1).

The countries included in the Leaders quadrant are characterized by high CSR standards, which are steadily followed by most companies, and also well-established communication channels.

\begin{tabular}{|c|c|c|c|}
\hline \multirow{4}{*}{ 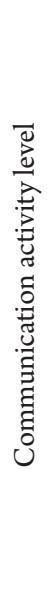 } & High & $\begin{array}{l}\text { Populists: } \\
\text { Japan } \\
\text { USA } \\
\text { Canada } \\
\text { Brazil } \\
\text { Slovakia }\end{array}$ & $\begin{array}{l}\text { Leaders: } \\
\text { Great Britain } \\
\text { France } \\
\text { Germany } \\
\text { Sweden } \\
\text { Austria } \\
\text { Australia } \\
\text { Taiwan }\end{array}$ \\
\hline & Low & $\begin{array}{l}\text { Beginners } \\
\text { South Africa } \\
\text { Romania } \\
\text { Bulgaria } \\
\text { Ukraine }\end{array}$ & $\begin{array}{l}\text { Conservatives } \\
\text { China } \\
\text { South Korea }\end{array}$ \\
\hline & & Low & High \\
\hline & \multicolumn{3}{|c|}{ Degree of CSR system formedness } \\
\hline
\end{tabular}

Figure 1. Matrix of countries' positioning by the level of CSR development, developed by KPMG

Source: The KMPG Reporting, 2013; Kulyeshova, 2013; Bodnaruk, 2016

This allows for a two-way dialogue between corporations and stakeholders. These include Britain, Germany, France, Sweden, Switzerland, the Netherlands, Spain, Italy, Portugal, Australia, India, and Taiwan.

The Populists quadrant covers countries where most companies demonstrate a high level of communication activity by disseminating information about their own principles, goals and ideas of social orientation, but lose as compared with "leaders" in the quality and completeness of the practical implementation of publicly proclaimed commitments. An example of such countries is Japan, the USA, Canada, Brazil, Slovakia, Israel, and others.

The countries that are a part of the Conservatives quadrant are the cell of corporations that, at a sufficiently high level of development of CSR systems, publish a rather limited array of information on achievements in this area. First and foremost, "conservatives" include China and South Korea.

The Beginners quadrant includes countries whose companies differ both by the low degree of formation of CSR systems and the low level of communication activity. These countries are South Africa, Romania, Bulgaria, Russia, Ukraine, and others.

According to the Memorandum on Corporate Social Responsibility in Ukraine, the definition of "social responsibility of business" should be understood as the responsible attitude of any company towards its product or service, consumers, employees, partners, active social position of the company, which consists in harmonious coexistence, interaction, and constant dialogue with society, participation in solving the most acute social problems.

Based on a study conducted by the European Commission's Directorate-General for Enterprise and Industry and aimed at identifying European companies involved in the process of implementing CSR, the main findings are (Shevchenko, 2014; Bodnaruk, 2016; Voronchak, 2018):

- involvement depends on the company size (48\% of small and $65 \%$ of medium companies apply CSR policy);

- the implementation of the CSR policy does not depend on the company sector, but there was a geographical discrepancy (for example, 33\% of the SME in France and $83 \%$ in Finland);

- among all the companies surveyed, half is involved in CSR;

- only $8 \%$ of the companies receive benefits or subsidies from the state for implementing CSR policies;

- more than $75 \%$ of SME representatives among respondents can identify the benefits of corporate social responsibility.

\subsection{Formation of conceptual fundamentals of the CSR strategy}

An analysis of the practice of adherence to the principles of social responsibility of business has enabled us to determine the factors affecting the effective functioning of its strategy.

1. The basic condition for socially responsible business is the implementation of conscientious business practice in relation to the main groups of stakeholders. On the one hand, such a practice implies the timely fulfilment of tax obligations in full, which directly influences the formation of the revenue part of the budget, the financing of state social programs. On the other hand, it involves transparency of business operations, including disclosure of information on financial and social issues and the verification of the corresponding reporting by independent auditing companies, which, in turn, contributes to the gradual reduction of the shadow economy in the country and the overcoming of the budget deficit. 
In the majority of the EU countries, state programs of support and stimulation of the abovementioned processes, in which the state defines socially responsible behaviour for business, engages private and public sector companies in the joint fulfilment of socially important tasks, stimulates business to socially responsible activity, are developed and operate (Martynyuk, 2015).

The theoretical and methodological basis for the integration of social responsibility into the strategy of company management is formed by a system-logical approach, according to which the integration of the mechanism of social responsibility into the strategy of company management - a long-term multistage process of developing a set of key elements and their alignment with the key elements of the company's strategy (Filipova, 2017).

In order to achieve positive results from integration, goals, tasks, tools, management processes, levels of responsibility, and expected results need to be coordinated, as well as ways of integration need to be selected.

It is proposed to coordinate strategic integration tools by three levels of management (strategic, tactical, operational) in the relevant groups: strategic, tactical, operational.

For this, it is expedient to distinguish three levels of responsibility:

I. Strategic-target (economic, legal, environmental) that is sufficient for the introduction of SR.

II. For information provided to the public (its transparency and accountability).

III. For companies' fulfilment of obligations to the environment, investors, future generations.

From the standpoint of sustainable development, the formation of an integration strategy can bring the following results:

- economic (growth of financial indicators and labour productivity, reduction of risks, an increase of capitalization, investment attractiveness and competitiveness of products, development of innovations);

- social: creating a positive image, strengthening trust in the company, etc. (Sukhoterina, Filyppova, 2015).

Relations between social responsibility and strategic management can be integrated through a process in the following main areas:

- formation of clear representations of company leaders about the content of social responsibility as a social phenomenon, in the development of which the company must participate;

- the transition from social program administration to the development of cost-effective communications between the company and the state and local communities; - strengthening of the company's relations with nonprofit organizations in determining SR priorities;

- improving the quality of business culture, the importance of ethical standards in public relations; - increasing the degree of information openness, developing new channels of communication with various social groups (Filipova, 2017).
According to the model of M. Porter and M. Kramer, there are two types of social responsibility: reactive and strategic, of which the company can choose (Porter, 2007):

1. Reactive type of SR, aimed at reducing existing problems and negative consequences of the company's business.

2. Strategic type of SR, which involves integrating the mechanism of social responsibility into the company's strategy and focus on creating long-term competitive advantages. This type changes the SR accent and means the transition from "social costs" to "social investment".

Implementation of the SR mechanism in the company's management strategy requires compliance with certain principles, methods and the development of appropriate management tools. Let's consider them in details.

Principles of SR integration. Formation of the SR system is based on a number of principles, which are proposed on the basis of the analysis of regulatory documents and best practices of the company (Antoshko, Krush, Tyulenyeva, 2013; Tretyak, 2014; Filipova, 2017):

- voluntary social responsibility, as it is its fundamental principle, and regulatory documents and international standards create conditions for the development of socially responsible business;

- accountability, because it provides the company with a regulatory basis for determining its role in social development and the impact of its activities on society and the environment;

- the rule of law, since the strict observance of the law is, firstly, the second universally accepted fundamental principle of SR, and secondly, provides for the clarity of rights and responsibilities of SR;

- transparency, which creates opportunities for clear disclosure in a truthful manner of information about policies, decisions, and activities the company is responsible for. Transparency is limited to commercial secrets, therefore, does not imply disclosure of official information that is protected in accordance with the laws or may lead to a breach of legal obligations;

- ethical principle, it contains three main components: a) ethical behaviour, allowing to adopt and apply standards of ethical conduct of the company sector; b) adherence to international standards of conduct that will facilitate the seizure of new global markets; c) respect for human rights, which will allow for the enforcement of human rights;

- interaction with stakeholders, it will allow to take into account the interests of all parties and interact with them, avoid the benefits of such situations. Their pressure affects the content and character of the company's SR strategy.

Guided by these principles, the company can further develop its own principles in the SR strategy in order to familiarize the personnel and all parties concerned with them. 


\section{Research results}

Integration of corporate social responsibility standards into management strategy

One of the biggest problems in the company's approach to social responsibility is the lack of integration of individual SR programs into the company's management strategy, as well as the "residual" principle of including socially responsible activities in the core one. This is because the company believes that the problems of society do not affect its activities. A more mature approach to socially responsible behaviour requires the integration of social programs and environmental issues into the management strategy of the company (Martynyuk, 2015).

A strategic approach to social responsibility involves expanding social responsibility beyond the scope of the solution of short-term, internal to the company's productive and social tasks. It is aimed at solving internal and external social, environmental, and economic problems that directly affect their core business activities in line with its strategic interests, with a view to longterm improving business sustainability.
In order to distinguish the main advantages of implementing the CSR standards in the management strategy, let's consider the matrix developed by Sustain Ability on the basis of an analysis of the activities of companies in Central and Eastern Europe (Table 3).

Since the social responsibility of business - awareness of the need for sustainable development, the matrix helps to identify key elements of the feasibility of the socially responsible business. The matrix is based on two groups of factors: on the one hand - factors of business success, on the other - factors related to sustainable development. Where the factors of sustainable development and business success factors converge, there is the possibility of defining a clear SRB feasibility condition. Improving corporate governance helps to improve access to capitals, increase revenues, and ensure the company's productivity growth. Work on improving environmental processes directly affects revenue and productivity growth and cost reduction. Effective human resource management helps to improve productivity (Dziekański Paweł, 2017). Taking

Table 2

Factors influencing the SRB strategy formation

\begin{tabular}{|c|c|c|c|}
\hline External factors & \multicolumn{2}{|c|}{ Internal factors by groups } \\
\hline Market structure & $\begin{array}{c}\text { Immaterial resources of a } \\
\text { company }\end{array}$ & Values & Stakeholder needs \\
\hline Competition & Human capital & $\begin{array}{c}\text { Social component } \\
\text { of the company's ideology }\end{array}$ & Personnel \\
\hline Market concentration & Social capital & Strategy & Cuppliers \\
\hline Stage of product/service lifecycle & Goodwill & National/global \\
\hline Market differentiation level & Stakeholder involvement & Intangible assets & Local companies \\
\hline Growth rate & Intangible capital & $\begin{array}{c}\text { Inconsistency of the strategy with the social requirements } \\
\text { of a particular market or its segment }\end{array}$ \\
\hline Barriers to entry the market & \multicolumn{2}{|c}{}
\end{tabular}

Source: Voronchak, 2018; Filipova, 2017

Table 3

Matrix of the appropriateness of SRB introduction

\begin{tabular}{|l|l|c|c|c|c|c|c|c|}
\hline & \multicolumn{2}{|c|}{ Corporate activity } & \multicolumn{2}{|c|}{ Environmental factors } & \multicolumn{2}{|c|}{ Socio-economic development } \\
\cline { 3 - 9 } & $\begin{array}{c}\text { Corporate } \\
\text { management }\end{array}$ & $\begin{array}{c}\text { Activity of } \\
\text { influence } \\
\text { groups }\end{array}$ & $\begin{array}{c}\text { Improvement } \\
\text { of ecological } \\
\text { processes }\end{array}$ & $\begin{array}{c}\text { Ecological } \\
\text { products and } \\
\text { services }\end{array}$ & $\begin{array}{c}\text { Environmental } \\
\text { development } \\
\text { of the area }\end{array}$ & $\begin{array}{c}\text { Social } \\
\text { development }\end{array}$ & $\begin{array}{c}\text { Human } \\
\text { resources } \\
\text { management }\end{array}$ \\
\cline { 2 - 9 } \\
\cline { 2 - 10 }
\end{tabular}

Matrix's legend.

\begin{tabular}{|l|l|}
\hline & Insignificant influence of conditions of the appropriateness of SRB introduction \\
\hline & There is no evidence of the appropriateness of SRB introduction \\
\hline & Significant influence of the conditions of SRB appropriateness \\
\hline
\end{tabular}

Source: Romanykha, 2016 
Table 4

Areas of improvement of strategic management on the basis of social responsibility standards

\begin{tabular}{|c|c|c|}
\hline & $\begin{array}{l}\text { Areas of development } \\
\text { of SRB strategic management }\end{array}$ & Characteristics of improvement measures \\
\hline \multirow{4}{*}{1} & \multirow{4}{*}{$\begin{array}{l}\text { Determination of SR } \\
\text { priorities }\end{array}$} & $\begin{array}{l}\text { Formation of clear representations of business, company executives about the content of SR } \\
\text { as a social phenomenon, in the development of which they must participate }\end{array}$ \\
\hline & & Inclusion of local community development into the system of strategic goals \\
\hline & & Calculation of the inevitability of changes in the economic situation \\
\hline & & Improving the quality of business culture, the importance of ethical standards \\
\hline 2 & Overcoming social nihilism & $\begin{array}{l}\text { The transition from administering social programs to the development of cost-effective ties between } \\
\text { the business, state, and local communities }\end{array}$ \\
\hline \multirow[b]{2}{*}{3} & \multirow{2}{*}{$\begin{array}{l}\text { Building relations of business } \\
\text { and society }\end{array}$} & Strengthening the company's relations with nonprofit organizations \\
\hline & & $\begin{array}{l}\text { Increasing the degree of information openness, preserving the structure of the addressees of the SR, } \\
\text { developing new channels of communication with various social groups }\end{array}$ \\
\hline \multirow{3}{*}{4} & \multirow{3}{*}{$\begin{array}{l}\text { Development of internal } \\
\text { standards and documents } \\
\text { on strategic management }\end{array}$} & Ensure mutual understanding and interaction with owners \\
\hline & & Attracting minority shareholders to the procedure of approval \\
\hline & & $\begin{array}{l}\text { To add solutions to specific social problems in the field of labour relations to the company's economic } \\
\text { development programs }\end{array}$ \\
\hline 5 & $\begin{array}{l}\text { Development } \\
\text { of SRB programs }\end{array}$ & $\begin{array}{l}\text { Development of a document containing directions for the development of social relations inside and } \\
\text { outside the company (Provisions on social programs). }\end{array}$ \\
\hline \multirow{4}{*}{6} & \multirow{4}{*}{$\begin{array}{l}\text { Formation of a complex of } \\
\text { CSR measures }\end{array}$} & Participation in activities carried out by the authorities and management of different levels \\
\hline & & $\begin{array}{l}\text { Development of measures to disclose information about the company's activities for the media and the } \\
\text { public of the local community, region, country }\end{array}$ \\
\hline & & Strengthening the relationship between the quality of products and services, the company's image \\
\hline & & $\begin{array}{l}\text { Improvement of the company's goodwill and target tasks (stable business environment; growth of } \\
\text { investment attractiveness or long-term capitalization of the company; reduction of non-financial risks) }\end{array}$ \\
\hline
\end{tabular}

into account all of the above, the following directions of improvement of the company's strategic management on the basis of social responsibility standards can be proposed.

Upon that, the mechanism of corporate social responsibility management is changing and differs from the known ones, which is defined differently. In particular, as a "set of interconnected functions of planning and analysis, motivation, control, as well as organizational and informational support, which create the basis for the continuous process of interaction of personnel, management of the organization, business owners (shareholders), local communities and the state" (Shevchenko, 2014).

\section{Conclusions}

Therefore, the social responsibility of business has important consequences for all economic and social agents of the business environment, as well as for state authorities that should take them into account when determining their own actions. If the state supports CSR and stimulates its development by creating a favourable socially safe environment for the activity of entrepreneurs, then the rates of development of the social activity of the company in the country are significantly increasing. The growth of social responsibility of business is a relevant problem of modernizing the economy and improving the sociolabour relations in each country in the modern period of global socio-economic development.
The formation of a national SRB model is not the copying of successful models but the use of the best world experience of each country, which should be objectively combined with the local traditions, mentality, and peculiarities of the requirements of local stakeholders for business. The main tool for creating an effective SRB model is the open dialogue of all stakeholders, social partnership, and the dissemination of knowledge about SRB, weighted state policy on entrepreneurship development.

Crisis phenomena observed in society have led many companies to strive for isolation in solving social responsibility issues in the period of economic instability. This is a false position because it arises as a result of the underdeveloped mechanisms of the formation and functioning of civil society and the low level of awareness of the company that it is only by building an effective dialogue with society and government they can get an effective result sustainable development. Also, integration of SR will allow the company to: create a positive image; improve goodwill; create a stable business environment; reduce non-financial risks; increase investment attractiveness; accelerate capitalization of the company in the long run.

The considered ways and approaches to the integration of the mechanism of social responsibility into the company's management strategy allow developing a strategy aimed at achieving both economic results and long-term social and responsible interaction with the external environment. They become the basis for 
further research into the applicability and integrity of the integration tools.

In order to accelerate social responsibility development trends, it is required to develop national CSR development programs. In this regard, at the state level, it is necessary to work on issues of social responsibility of public authorities, to develop relevant legislative acts on CSR regulation and improvement, and to extend the companies' exchange of best practices in evaluating the economic efficiency of projects.

\section{References:}

Analytics (2017). Social responsibility of business. Information and analytical material. Retrieved from: http://www.svb.org.ua

Antoshko, T.R., Krush, P.V., Tyulenyeva, Yu.V.(2013).Vprovadzhennya korporatyvnoyi sotsialnoyi vidpovidalnosti na promyslovykh pidpryyemstvakh [Implementation of corporate social responsibility at industrial enterprises]. Kyiv: NTUU "KPI". (in Ukrainian)

Baffett, U. (2008). Esse ob investitsiyakh, korporativnykh finansakh i upravlenii kompaniyami [Essay on investment, corporate finance and company management]. Moscow: Alpina Business Books.

Belyavska, K. S. (2011). Sotsialna vidpovidalnist biznesu: evolyutsiya pohlyadiv na problemu. [Social responsibility of business: the evolution of views on the problem]. Visnyk Khmelnytskoho natsionalnoho universytetu, 1, 228-334.

Berezina, O. Yu. (2010). Suchasni modeli korporatyvnoyi sotsialnoyi vidpovidalnosti [Modern models of corporate social responsibility]. Ekonomichnyy prostir: zb. nauk. pr. Dnipropetrovsk: PDABA, 41, 194-202.

Bodnaruk, O. (2016). Yevropeyskyy dosvid derzhavnoho rehulyuvannya korporatyvnoyi sotsialnoyi vidpovidalnosti [European experience of state regulation of corporate social responsibility]. Visnyk DonDUU. Menedzher, 2(71), 41-48.

Dziekański Paweł (2017). Economic effectiveness of the activities of local self-government units in the light of the municipality financial resources. Naukovyy visnyk Polissya, 3(11), 1. doi: 10.25140/2410-9576-2017-1-3(11)-76-82

Filipova, S. (2017). Sotsialna vidpov_dalnist at the strategy i upravleninya v tchiznyan p_dprie€stvom: problemni nutrition nutrition itinteruvannya mehanizmu. ECONOMICS: time reatitie, 2(30). Retrieved from: https://economics.opu.ua/files/archive/2017/No2/5.pdf

Friedman, M. (1970). The Social Responsibility of Business is to Increase its Profits. The New York Times. Magazine, September 13. Retrieved from: http: //www.colorado.edu/studentgroups

KMPG International Survey of Corporate Social Responsibility Reporting (2011). Retrieved from: http://www.kpmg.com/GR/en/IssuesAndInsights/ArticlesPublications/Sustainability/Documents

KMPG Survey of Corporate Social Responsibility Reporting (2013). Retrieved from: www.kpmg.com/Global/ en/IssuesAndInsights/ArticlesPublications/corporate-responsibility/Documents / corporate-responsibilityreporting-survey-2013-exec-summary.pdf

Kotler, P., Li, N. (2005). Korporatyvna sotsialna vidpovidalnist. Yak zrobyty yakomoha bilshe dobra dlia vashoi kompanii ta suspilstva [Corporate social responsibility. Doing the most good for your company and your cause]. Kyiv: Standart. (in Ukrainian)

Khamidova, A. (2017). Korporatyvna sotsialna vidpovidalnist yak faktor pidvyshchennya efektyvnosti mekhanizmu derzhavnoho rehulyuvannya ekonomiky [Corporate social responsibility as a factor of increasing the efficiency of the mechanism of state regulation of the economy]. Retrieved from: http://www.csrjournal. com/news/2661-korporativna-socialna-vidpovidalnist-yak-faktor-pidvishhennya-efektivnosti-mexanizmuderzhavnogo-regulyuvannya-ekonomiki.html

Kulyeshova, L. V. (2013). Korporatyvna sotsialna vidpovidalnist yak instrument staloho rozvytku pidpryyemstv [Corporate social responsibility as an instrument for sustainable development of enterprises]. Visnyk Donbaskoyi derzhavnoyi mashynobudivnoyi akademiyi, 1(30), 195-199.

Martynyuk, O. A. (2015). Formation of the imperatives of sustainable development for structural transformations of the economy. Bulletin of the Odessa National University. Series: Economics, 20(6), 44-48.

Mazurenko, V. P. (2011). Suchasna kontseptsiya korporatyvnoyi sotsialnoyi vidpovidalnosti u mizhnarodnomu biznesi [Contemporary concept of corporate social responsibility in international business]. Efektyvna ekonomika. Retrieved from: http://www.economy.nayka.com.ua/?op=1\&z=1199

Olijnik, O. R. (2015). Mizhnarodnij dosvid rozvitku socialnoyi vidpovidalnosti ta mozhlivist jogo zastosuvannya $\mathrm{v}$ Ukrayini [International experience of corporate social responsibility and the possibility of its application in Ukraine]. Innovacijna ekonomika: naukovo-virobnichij zhurnal, 4(59), 37-44.

Porter Michael (2007). Theory of social responsibility. Financial Times. - October 1, 2007. Retrieved from: http://blogs.ft.com/businessblog

Ramazanov, A. (2007). Kontseptsiya korporatyvnoyi sotsialnoyi vidpovidalnosti. Problemy teoriyi ta praktyky upravlinnya. Concept of Corporate Social Responsibility. Problems of the theory and practice of management. Kyiv: Energy.

Reznyk, N. (2014). Sotsialna vidpovidalnist biznesu: sutnisno-teoretychni aspekty [Social responsibility of business: essentially theoretical aspects]. Zhurnal Yevropeyskoyi Ekonomiky. Veresen, 296-303.

Romanykha, O. (2016). Corporate social responsibility development in Ukraine Bulletin of the Khmelnytsky National University. Economic Sciences, 2(1). Retrieved from: http://nbuv.gov.ua/UJRN/Vchnu_ekon_2016_2(1) 
Sardak, S.E., Haslenko, K. S. (2017). Vnutrishnya korporatyvna sotsialna vidpovidalnist pidpryyemstva: teoretychni ta praktychni aspekty [Internal corporate social responsibility of the enterprise: theoretical and practical aspects]. Retrieved from: http://economyandsociety.in.ua/journal/12_ukr/57.pdf

Shevchenko, O. (2014). Regulation of the corporate social responsibility policy: the practice of the member states of the European Union. Actual problems of international relations. Release 122 (part I).

Social Responsibility - The Basis of Business Philosophy (2016). Retrieved from: filosofii-biznesu

Socialna vidpovidalnist biznesu (2017): rozuminnya ta vprovadzhennya [Corporate social responsibility: understanding and implementation]. Retrieved from: http://www.un.org.ua/files/Concept_Paper.pdf

Sofiyenko, A.V. (2012). Sotsialna vidpovidalnist biznesu: rozuminnya ta suchasni tendentsiyi. [Social responsibility of business: understanding and current trends. Economic innovation]. Ekonomichni innovatsiyi, 47, 297-301.

Sukhoterina, M. I., Filyppova, S. V. (2015). Ekolohichna skladova sotsialnoyi vidpovidalnosti mashynobudivnoho pidpryyemstva [Ecological component of social responsibility of machine-building enterprise]. Ekonomika: realiyi chasu, 1 (17), 204-208. Retrieved from: http://economics.opu.ua/files/archive/2015/n1.html (in Ukrainian)

Tretyak, M.V.(2014). Typolohiya sotsialnoyi vidpovidalnosti biznesu [Typology of corporate social responsibility]. Teoriya ta praktyka derzhavnoho upravlinnya, 4(47), 1-10. (in Ukrainian)

Voronchak, I. O. (2018). National models of social responsibility of business: features and mechanism of formation of Mukachevo State University, № 17. Retrieved from: http://economyandsociety.in.ua/journal/17_ukr/4.pdf

United Nations Global Compact. Retrieved from: http://www.unglobalcompact.org./participants/search Zhmay, O. (2015). Corporate Social Outlook: Perspectives and Motivation for the Small Business in Ukraine. Market economy: modern management theory and practice. Vol. 14. Issue 2(30). Retrieved from: http://rinek.onu.edu.ua/ article/view/61700 